\section{En finger på pulsen}

I min familie hadde ingen i foreldregenerasjonen mer enn folkeskole, middelskole, kveldskurs eller fagbrev. Vi barna hadde examen artium som mål, flere fikk det, og noen gikk videre. For mine barn var høyere utdanning en selvfølge. Som lege er jeg et ektefødt barn av den norske velferdsstaten. Samfunnet bekostet utdanningen. Med på kjøpet fulgte skolemelk, helsekontroller, vaksinasjoner og «tannrøkta». Min generasjon fikk nyte godt av Studentsamskipnaden med 50 kroner i semesteravgift og Statens lånekasse med avdragsfrie lån og markedsuavhengige renter.

Ideer om en «velferdsstat» slo rot tidlig på 1900-tallet, skjøt fart $i$ årene før annen verdenskrig og ble gradvis en realitet i tiårene etter krigen. Blant mye annet gjaldt det spørsmål om utdanning, anstendige bo- og arbeidsforhold og helsetjenester. Selv om folketrygdloven fra 1967 var et tverrpolitisk løft, kom ikke velferdsstaten av seg selv. Den var ikke resultatet av offentlige utredninger, oppsto ikke i styrerommene og rundt forhandlingsbordet - eller på bedehusene for den saks skyld. Den sprang ut av nød, nedverdigelse, raseri og trass. Svaret var felles samhold og kollektive løsninger.

Årtusenskiftet bød på nye politiske impulser. Det finnes ingen god norsk oversettelse for New Public Management (NPM), men meningen og innholdet var ikke til å ta feil av i. Hovedprinsippene er hel eller delvis privatisering av offentlige tjenester og konkurranseutsetting til private tjenestetilbydere. Helse- og sosialtjenester er intet unntak. Det er etableringen av helseforetakene et godt synlig bevis på. Produksjon, tjenesteyting, effektivisering, standardiserte pakkeforløp og bunnlinje er de nye faneordene. Da sykehusdirektøren ved St. Olavs hospital her om året ønsket avgangskullet på medisinstudiet lykke til, håpet han at de hadde lært nok til å kunne hjelpe ham med å holde budsjettene. Tidligere helseminister Bjarne Håkon Hansen lovpriste et besøk på Toyota-fabrikken og håpet at helsetjenesten kunne fungere likedan. Kan det bli gode samaritanere av sånt?

Streiken blant leger og andre i Akademikerne helse kan bære bud om et hardere klima i det offentlige arbeidslivet (1), selv om begge parter hevdet at utgangspunktet var å slå ring rundt velferdsstaten. Samfunnsansvar, ropte den ene. Forsvar for pasientbehandling og -sikkerhet, svarte den andre. Dette kan gi inntrykk av at staten er på vei ut i spagaten. Velferdsgarantien til velgerne har etter hvert fått frem en arbeidsgiverstil med sterke likhetstrekk til «de harde trettiåra». I tråd med eldre paroler står leger og andre fast på at de gjerne gjør sin plikt, samtidig som de fortsatt krever rett til innflytelse på egen jobbsituasjon.

Togførernes streik mot NSB løp parallelt med vår. Den handlet også om fag og sikkerhet, og motpartens retorikk var den samme. Statens jernbaner har lenge vært delt $i$ et eierselskap - Jernbaneverket - mens NSB står for passasjerbefordringen. Gjentatte ganger fortalte NSB-direktøren at persontransporten i Norge skal ut på anbud. Om de går med på togførernes krav, vil selskapet miste et viktig fortrinn og risikerer å tape konkurransen. Kan helseministeren bli slått av samme tanke? I dag eier og driver staten spesialisthelsetjenesten gjennom helseforetakene. Kan et neste skritt innebære en oppsplitting i en eierdel - «Sykehusverket»med bygninger og utstyr, og en driftsdel, gjerne kalt «Pasientbefordringen»? Sistnevnte kan vel settes ut på anbud? Det åpner helt nye perspektiver. Smak på tanken om å bli overdratt til utenlandske eiere! En dyster spådom er at det kan skje før utgangen av det neste tiåret.

Store og små konflikter trenger sine ledere, som i den nylig avsluttede legestreiken. Jeg trekker gjerne frem Trude Basso (38), lege i spesialisering i ortopedisk kirurgi ved St. Olavs hospital med tre barn og en ph.d.-grad. Hun talte makta midt imot blant annet med kraftfulle brev til sin egen direktør (2). Talspersoner i konflikter kan oppnå heltestatus blant sine egne, men oppfattes og behandles som bråkmakere og oppviglere av motparten. Tanken slår meg: Hva vil skje med Basso den dagen hun står med munnbindet $i$ hånden og spør om fast ansettelse som overlege? Svaret avhenger av hvilket faglig fellesskap hun fortsatt har i ryggen.

Det var neppe tilfeldig at kampsangen under legestreiken hentet inspirasjon fra og var skåret over samme musikalske lest som forestillingen Les Misérables. Sluttscenen - anført av opprørske studenter - foregår mot et bakteppe av Paris-revolusjonen i 1830. Vår sang fulgte nesten hvert TV-innslag om saken.

Sangen har tonet ut, støvet har lagt seg og er avløst av stillheten etterpå (3). Erfarne leger har forstått at hardt tilkjempede, kollektive ordninger står på spill og til syvende og sist vil ramme pasientene og samfunnet. Yngre leger har fattet at streiken og bekymringen for velferdsstatens utvikling kan påvirke håpet om det «gode liv som lege» (4). Til tross for forsiktige innspill fra helseminister Bent Høie (H) om behovet for å (gjen)opprette tilliten mellom partene (5) og stortingsrepresentant Torgeir Micaelsens (Ap) analyse om to virkeligheter og at New Public Management neppe kan pålegges skylden for alt som er galt (6), er det ennå få lysglimt i tunnelen.

Takk til Tore Wergeland Meisingset, turnuslege og ph.d. for hjelp under arbeidet med manuskriptet.

\section{Litteratur}

1. Vangsnes L-E. Kampen for forsvarlighet. Tidsskr Nor Legeforen 2016; 136: 1603

2. Basso T. Trappa har fått for mange trinn. Dagens Medisin 27.9.2016. http://dagensmedisin.no/artikler/2016/09/27/trappa-har-fatt-for-mange-trinn/ (14.11.2016)

3. Brean A. Stillheten etterpå. Tidsskr Nor Legeforen 2016; 136: 1597.

4. Dommerud T. Derfor streiker legene - og derfor varer streiken så lenge. Aftenposten 7.10.2016. http://aftenposten.no/meninger/nyhetsanalyse/Derfor-streikerlegene---og-derfor-varer-streiken-sa-lenge-606154b.html (14.11.2016).

5. Høie B. Streiken er over - hva nå? Dagens Medisin 20.10.2016. http://dagensmedisin.no/artikler/2016/10/20/streiken-er-over--hva-na/ (14.11.2016).

6. Storvik AG. - Parallelle virkeligheter i sykehusene. Dagens Medisin 25.10.2016 http://dagensmedisin.no/artikler/2016/10/25/--parallelle-virkeligheter-isykehusene/ (14.11.2016). 